\title{
Feed supplementation and weight change, milk yield and post-partum oestrus in Desi cows
}

\author{
M. G. S. Alam*, M. A. Rahman¹, M. Khatun and J. U. Ahmed² \\ Department of Surgery and Obstetrics, Faculty of Veterinary Science, Bangladesh \\ Agricultural University, Mymensingh, Bangladesh
}

\begin{abstract}
A feeding trial was performed with 16 multiparous lactating Desi (indigenous) cows for 32 weeks to evaluate the effects of dhaincha (Sesbania aculeata) and ipil-ipil (Leucaena leucocephala) as alternative sources of protein together with urea-treated straw, fish meal, green grass and urea molasses mineral block (UMMB) on body weight, milk yield and resumption of ovarian cyclicity after parturition. Cows were grouped into four and supplied four diets. Cows in groups B (dhaincha, ipil-ipil, treated straw, fish meal and common salt), group C (UMMB and green grass), and group A (treated straw, fish meal and common salt) gained body weight $20.7 \pm 2.1,17.2 \pm 1.3$ and $15.4 \pm 3.6 \mathrm{~kg}$, respectively, over a period of 32 weeks. Non-supplemented cows (group D) lost body weight an average of $12.5 \pm 5.4 \mathrm{~kg}$. Among the supplemented cows, significantly $(\mathrm{P}<0.05)$ better weight gain was observed in group $B$ than groups $C$ and $A$. The difference in weight gain between $B$ and $C$, and $C$ and $A$ were not significant $(P>0.05)$. Significantly $(P<0.01)$ higher milk yield was observed in groups $B, C$ and $A$ than in $D$. There were no significant $(\mathrm{P}>0.05)$ differences in milk yield between groups $\mathrm{B}, \mathrm{A}$ and $\mathrm{C}$. The animals of group $\mathrm{C}, \mathrm{B}$ and A expressed behavioural oestrus 84-190 (149.0 \pm 46.3$), 131-220(178.0 \pm 32.0)$ and 179$218(200.5 \pm 14.0)$ days postpartum, respectively, these were not significantly $(\mathrm{P}>0.05)$ different. None of the cows in group D manifested oestrus during the study period. It is suggested that feed supplementation during lactation in cows stimulates ovarian cyclicity earlier. Dhaincha and ipil-ipil could be used as alternative sources of protein for ruminants, which may result in better weight gain, milk yield and reproductive performance during postpartum period in indigenous cows. (Bangl. vet. 2009. Vol. 26, No. 2,39-47)
\end{abstract}

\section{Introduction}

Desi Zebu cattle have low fertility (Chopade et al., 2002) and produce $0.7 \mathrm{~kg}$ milk/day (Bari, 1987). The average live weight of Desi Zebu cows is about $150 \mathrm{~kg}$, which is $25-30 \%$ less than that of Indian Zebu cattle (Jackson, 1981). The poor physical condition and low reproductive performance are mostly due to consumption of insufficient and imbalanced feed along with parasitic infestation. The feed deficit becomes more serious in floods, monsoons and droughts. The feed shortage, especially of forages, is one of the main constraints in livestock development.

\footnotetext{
${ }^{1}$ Upazila Livestock Office, Jherkorgacha, Jessore, Bangladesh

*Correspondence: E-mail:- mgsalam52@yahoo.com
} 
As the human population increases, pressure on land becomes higher and man and livestock are competing for the products of land. On the other hand, pasture land is limited. Rice straw is the major cattle feed, contributing $87 \%$ of the total dry roughage, but straw has a low nutritive value due to lower crude protein (4\%) and 5 MJ ME/kg dry matter, and its digestible crude protein is near zero and total digestible nutrients content is about 48\%, which is also low (Akbar and Khaleduzzaman, 2009). It is also deficient in essential minerals with indigestible cellulose and hemicelluloses (Jackson, 1977). Therefore, improving the feeding value of rice straw is very important. Urea treatment of straw improves the digestibility (Haque and Akbar, 1986; Schiere et al., 1988) and intake under local condition (Saadullah et al., 1981). To obtain better performance of cattle with only treated straw is difficult. Some quality protein may be supplied for better utilization of treated straw. Preston and Willis (1970) demonstrated that feed intake and growth could be stimulated by inclusion of dietary by-pass protein (Fish meal) to a low-protein fibrous diet. Urea can also be incorporated in ruminant ration in UMMB. UMMB with a straw-based diet increased digestibility of straw, which in turn improves reproductive performance (Ghosh et al., 1993; Alam et al., 2006).

Fish meal is a source of by-pass protein for lactating cows but sometimes scarce and expensive. Ipil-ipil and dhaincha are used as alternative sources of protein. IpilIpil, a tropical fast-growing plant, has been identified as a protein-rich fodder for livestock (Joshi and Upadhaye, 1976). Dhaincha is a legume suitable as a fodder for livestock, and was tried in India (Katiyer and Ranjhan, 1969). The present study was undertaken to investigate the effect of ipil-ipil and dhaincha as protein sources with treated straw, fish meal and UMMB on the resumption of ovarian cyclicity, milk yield and body weight changes after calving in Desi Zebu cows.

\section{Materials and Methods}

Housing and management

A total of 16 multiparous lactating Desi Zebu cows were divided into four groups (A, B, C, D), weighing $129.8 \pm 7.0$ (Group-A), $135.2 \pm 6.4$ (Group-B), $138.9 \pm$ 5.8 (Group-C) and $133.4 \pm 9.4$ (Group-D) kg, respectively. All cows were kept on concrete floors in individual stall in a well-ventilated face-out stanchion barn. Animals were vaccinated against foot and mouth disease, anthrax and haemorrhagic septicaemia. All cows were dewormed orally using bolus containing tetramisole hydrochloride $(2.0 \mathrm{~g})$ and oxyclozanide $(1.2 \mathrm{~g})$ per $100-150 \mathrm{~kg}$ body weight (Levanid ${ }^{\circledR}$, The ACME Laboratories Ltd., Dhaka, Bangladesh).

\section{Feeding of animals}

The animals were assigned to four rations: feeds were supplied in a separate manger as follows:

Group A received $9.3 \mathrm{~kg} 5 \%$ urea-treated rice straw with $0.2 \mathrm{~kg}$ fish meal and $0.1 \mathrm{~kg}$ common salt daily. 
Group B were allowed $9.4 \mathrm{~kg} \mathrm{5 \%}$ urea-treated rice straw with $0.1 \mathrm{~kg}$ fish meal and 0.1 $\mathrm{kg}$ common salt, $0.7 \mathrm{~kg}$ dhaincha and $0.8 \mathrm{~kg}$ ipil-ipil daily.

Groups $\mathrm{C}$ were grazing for 6.5 hours every day. All animals were supplied an average of $4.9 \mathrm{~kg}$ green grasses with $0.4 \mathrm{~kg}$ UMMB daily as evening meal.

Group D (control) had access to grazing for the whole day.

All animals had fresh drinking water ad libitum and were observed throughout the experiment.

Daily intake of feed is shown in Table 1.

Table 1. Daily intake of feed ( $\mathrm{kg} /$ day) of cows

\begin{tabular}{l|c|c|c|c}
\hline \multicolumn{1}{c|}{ Feed ingredients } & Group A & Group B & Group C & Group D \\
\hline Urea treated rice straw & 9.3 & 9.4 & - & - \\
Fish meal & 0.2 & 0.1 & - & - \\
Ipil-ipil & - & 0.8 & - & - \\
Dhaincha & - & 0.7 & - & - \\
UMMB & - & - & 0.4 & - \\
Green grass & - & - & 4.9 & - \\
Common salt & 0.1 & 0.1 & - & - \\
Grazing (hours/day) & & & 6.5 & 24 \\
Water & ad libitum & ad libitum & ad libitum & ad libitum \\
\hline
\end{tabular}

Preparation of urea-treated straw

Rice straw was treated with 5\% urea as described by Dolberg et al. (1980). A measured amount of straw was sprayed with $5 \%$ urea solution on a concrete floor, and then covered with two layers of polythene sheets to make it air-tight for 10 days.

Preparation of $U M M B$

Fresh molasses, urea, common, salt, calcium oxide, fish meal, oil cake and vitamin-mineral premixes (Embavit ${ }^{\circledR}$; Rhone-Poulenc, Dhaka, Bangladesh) and wheat bran were purchased from the local market. Urea, common salt and Embavit ${ }^{\circledR}$ were mixed with molasses. Then the binding agent (calcium oxide) was mixed thoroughly. Wheat bran previously mixed with fish meal and oil cake was slowly incorporated and mixed thoroughly by hand on a concrete floor. After mixing it was placed in a brick-shaped wooden frame to prepare block and covered by polythene foil (Ghosh et al., 1993). Ingredients of the UMMB are shown in Table 2.

\section{Proximate analysis of the feed stuffs}

The components of the feeds stuffs were analysed according to AOAC (2000) (Table 3). 
Table 2. Composition of urea-molasses-mineral block

\begin{tabular}{l|c}
\hline \multicolumn{1}{c|}{ Feed ingredients } & Percentage \\
\hline Molasses & 55 \\
Wheat bran & 25 \\
Fish meal & 3 \\
Calcium oxide $(\mathrm{CaO})$ & 4.5 \\
Urea & 4 \\
Til oil cake & 5 \\
Embavit & 2.5 \\
Common salt $^{\circledR}$ & 1 \\
\hline
\end{tabular}

Table 3. Proximate analysis of feed ingredients in experimental rations

\begin{tabular}{l|c|c|c|c|c|c|c}
\hline \multirow{2}{*}{ Ingredient } & \multirow{2}{*}{ DM (\%) } & \multicolumn{6}{c}{ On dry matter basis (\%) } \\
\cline { 3 - 8 } & & $\mathrm{CP}$ & $\mathrm{CF}$ & Ash & EE & OM & NFE \\
\hline Urea (5\%) treated rice straw & 40.2 & 7.4 & 31.5 & 14.9 & 2.0 & 85.1 & 44.3 \\
Fish meal & 87.5 & 55.9 & 1.8 & 17.8 & 2.6 & 82.2 & 21.9 \\
Dhaincha & 25.8 & 22.2 & 19.3 & 7.5 & 3.7 & 92.5 & 47.3 \\
Ipil-ipil & 30.3 & 24.4 & 15.7 & 6.9 & 4.6 & 93.1 & 48.5 \\
Green grasses & 20.4 & 7.4 & 28.7 & 8.4 & 2.3 & 91.7 & 53.3 \\
UMMB & 76.3 & 29.6 & 2.3 & 16.0 & 0.5 & 84.1 & 51.8 \\
\hline
\end{tabular}

$\mathrm{DM}=$ dry matter, $\mathrm{CP}=$ crude protein, $\mathrm{CF}=$ crude fibre, $\mathrm{EE}=$ ether extract, $\mathrm{NFE}=$ Nitrogen free extract, $\mathrm{OM}=$ organic matter

\section{Voluntary intake}

The rations were supplied to groups A \& B twice daily, in the morning and evening. In case of group $C$, the feeds were given once daily in the evening. Cows consumed all the concentrates and green grass but sometimes refused treated straw. For measuring voluntary consumption, straw was weighed every day before supplying to the cow; next morning left over straw was weighed.

Measurement of body weight

The weights of animals were estimated by measuring length and girth using the Shaeffer's formula as described by McNitt (1983). The animals were measured at the beginning of the experiment for three consecutive days and the average taken. Then the animals were measured weekly throughout the experiment of 32 weeks. The final measurement was taken as the average of the last three days. 
Milk yield

The cows were hand-milked twice a day with the calf at foot. Daily milk yield was recorded.

\section{Detection of oestrus}

Cows were observed for one hour in early morning and evening to detect behavioural oestrus. Postpartum oestrus intervals were calculated as interval between the date of calving and the date of first observed oestrus.

\section{Statistical analyses}

The experiment was completely randomized design and data were analysed statistically according to Steel and Torrie (1960). The results unless otherwise stated are expressed as mean \pm standard deviation (Mean \pm S.D.).

\section{Results and Discussion}

The estimated body weights are summarized in Table 4. Animals of supplemented groups (B, C, A) increased in estimated body weight by $15.3 \%$ (20.7 \pm $2.1 \mathrm{~kg}), 12.4 \%(17.2 \pm 1.3 \mathrm{~kg}$.) and $11.9 \% 15.4 \pm 3.6 \mathrm{~kg})$, respectively. On the contrary, cows on grazing only (Group D) lost 9.3\% (12.5 $\pm 5.4 \mathrm{~kg})$ of estimated weight in the same period. Body weight gain of group B (treated straw, fish meal, common salt, dhaincha and ipil-ipil) was highest followed by groups C (UMMB \pm green grasses) and A (treated straw, fish meal and common salt).

Body weight change is a major determinant of postpartum reproduction (Sasser et al., 1988; Butler and Smith, 1989). The increase of body weight in group B probably would have been due to better assimilation of protein from dhaincha, ipil-ipil and fish meal and better conversion to body tissue. The findings are in agreement with those of Khan et al. (1990), who observed the beneficial effect of dhaincha and ipil-ipil on performance when partly replacing fish meal in local Zebu cows. Ghosh et al. (1993) found that UMMB plus green grass supplementation improved body condition.

Average milk yield of groups B, C, A and D were $1.5 \pm 0.2,1.5 \pm 0.2,1.4 \pm 0.1$ and $0.7 \pm 0.3 \mathrm{~L} /$ day, respectively (Table 4$)$. There was significantly higher $(\mathrm{P}<0.01)$ milk yield in cows of supplemented groups compared to non-supplemented group, but no significant $(\mathrm{P}>0.05)$ differences in milk yield between the supplemented groups.

Milk production in supplemented cows increased up to two or three months after calving, then gradually decreased. The milk yield slightly increased in nonsupplemented cows during first month after calving and then severely decreased. This result indicated that the cows cannot fulfil their nutrient requirements through only grazing. Although, higher milk yield was observed in group B and C than in D, it was not satisfactory. A question may arise that milk production was not promising in comparison to feeding. This might be due to the low digestibility of diets and low genetic potential. 
Table 4. Estimated body weight changes and milk yield

\begin{tabular}{l|c|c|c|c}
\hline \multirow{2}{*}{ Parameters } & \multicolumn{4}{c}{ Group } \\
\cline { 2 - 5 } & $\mathrm{A}$ & $\mathrm{B}$ & $\mathrm{C}$ & $\mathrm{D}$ \\
\hline Initial estimated body weight $(\mathrm{kg})$ & $129.8 \pm 7.0$ & $135.2 \pm 6.4$ & $138.3 \pm 5.9$ & $133.4 \pm 9.4$ \\
Final estimated body weight $(\mathrm{kg})$ & $145.2 \pm 7.3$ & $155.9 \pm 7.0$ & $155.5 \pm 4.7$ & $120.9 \pm 12.9$ \\
Net estimated weight gain $(\mathrm{kg})$ & $15.4 \pm 3.6$ & $20.7 \pm 2.1$ & $17.2 \pm 1.3$ & $-12.5 \pm 5.4$ \\
Body weight gain (g/day) & $68.9 \pm 5.3$ & $92.2 \pm 3.1$ & $76.8 \pm 2.5$ & $-55.6 \pm 4.3$ \\
Milk yield (L/day) & $1.4 \pm 0.1$ & $1.5 \pm 0.2$ & $1.5 \pm 0.2$ & $0.7 \pm 0.3$ \\
\hline
\end{tabular}

The cows of group C, B (except cow No. 537) and A, expressed behavioural first oestrus within 84-190 (148.7 \pm 46.3$), 131-220(178.0 \pm 33.0)$ and 179-218 (200.5 \pm 14.0$)$ days postpartum, respectively (Table 5). On the other hand, the cows of group D did not manifest behavioural oestrus during the study period. The value was converted to $\log$ value and analysis of variance was done. There was significant difference $(\mathrm{P}<0.01)$ between supplemented and control groups, but no significant $(\mathrm{P}>0.05)$ differences between groups $\mathrm{C}, \mathrm{B}$ and $\mathrm{A}$.

Table 5. Onset of first behavioural oestrus after parturition (days)

\begin{tabular}{c|c|c}
\hline Animal groups & Range (days) & Mean \pm SD (days) \\
\hline A & $179-218$ & $200.5 \pm 14.0$ \\
B & $131-220$ & $178.0 \pm 33.0$ \\
C & $84-190$ & $148.7 \pm 46.3$ \\
D & \multicolumn{2}{c}{ No oestrus observed } \\
\hline
\end{tabular}

The reproductive efficiency of cows after calving is largely dependent on the diet (Carroll et al., 1988; Butler and Smith, 1989). In general, protein is regarded as less important than energy for reproduction, but low protein intake may reduce fertility. Sasser et al. (1988) observed 75 days first oestrus interval after calving in adequately fed heifers compared to 86 days in protein-restricted heifers. Improved nutrition before calving reduced the onset of postpartum anoestrus period in taurine cows (Peters and Riley, 1982). Patil and Deshpande (1981) found that Gir cows with body weight gain following calving showed oestrus within 90 days, while those with body weight loss remained anoestrus. If body weight loss exceeds $10 \%$ then there is likely to be poor fertility (Morris, 1976). Urea incorporated in a fibrous diet increases body weight and milk production (Saadullah et al., 1981). Fish meal may act as a bypass protein $(65-60 \%)$, which is only partially degraded in rumen $(35-40 \%)$ and supports the protein requirement of lactating cows. It is necessary to meet the deficiency of dietary protein, which directly degraded in the rumen. Use of UMMB containing fish meal may play an important role in maintenance and gaining in body weight (Neric et al., 1984). Green grass has potential value as animal feed for enhancement of reproduction, because this can supply beta-carotene, which 
stimulates the corpus luteum to produce progesterone. Dhaincha and ipil-ipil is rich in protein and helps meet the protein requirement of high yielding cows. All the cows that gained body weight expressed behavioural oestrus earlier than the control (Patil and Deshpande, 1981; Alam et al., 2006). In this study, cow (\# 537) of group B manifested no behavioural oestrus during the experimental period. Estimated body weight and milk production were better in supplemented than in non-supplemented cows, where weight loss and low milk yield were due to underfeeding. Milk production requires energy and the animal is unable to meet the nutritional requirement through grazing alone, which in turn interferes with endocrine functions, especially the hypothalamo-pituitary-ovarian axis (Rutler and Randel, 1984; Whishnant et al., 1985). When the energy requirement in an adult animal is low, follicles fail to mature and follicular atresia results, with a loss of sexual desire followed by anoestrus. Morris (1976) agreed that the highest rate of subfertility was found in cows in poorest body condition.

It is suggested that energy balance in early lactation is important in determining the time of onset of ovarian cyclicity (Butler et al., 1983). Body weight loss in early lactation lead to reduced fertility, which is characterized by delayed onset of oestrus and lowered pregnancy rate (Haresign, 1980).

\section{References}

Akbar MA, Khaleduzzaman ABM 2009: Feeds and Feeding: Survey of Feedstuff Availability. In Handbook of Dairy Nutrition - Bangladesh, Edited by Robinson PH, Krishnamoorthy U, Anand PEV, American Soybean Association, International Marketing, Creati Views, New Delhi, India. pp. 117-135.

Alam MGS, Azam MS, Khan MJ 2006: Supplementation with urea and molasses and body weight, milk yield and onset of ovarian cyclicity in cows. Journal of Reproduction and Development 52 529-535.

AOAC 2000: Official Methods of Analysis. 17th Edn. Association of Official Agricultural Chemists, Washington, DC, USA

Bari AKF 1987: Present condition and problems in education for rural development with an emphasis on feed production from waste products and new resources. Proceeding of the Obihiro Asian Seminar on Education for Rural Development (OASERD), September 17 - 30, Obihiro University of Agriculture and Veterinary Medicine, Japan.

Butler WR, Everett RW, Coppock CE 1983: The relationships between energy balance, milk production and ovulation in postpartum Holstein cows. Journal of Animal Science 53 742-748.

Butler WR, Smith RD 1989: Inter-relationships between energy balance and postpartum reproductive function in dairy cattle. Journal of Dairy Science 72 767-783.

Carroll DJ, Barton BA, Anderson GW, Smith RD 1988: Influence of protein intake and feeding strategy on reproductive performance of dairy cows. Journal of Dairy Science 71 3470-3481.

Chopade MM, Ali SZ, Kuralkar SV 2002: comparative study of $F_{1}$ and $F_{2}$ crossbred cows with reference to productive traits. Indian Journal of Animal Sciences 72 916-917. 
Dolberg F, Saasullah M, Haque M, Ahmed R, Haque R 1980: Different ways of keeping straw during treatment with urea and urine. First Asian-Australian Animal Science Conference, September 2-6, Serdang, Selangor, Malaysia.

Ghosh A, Alam MGS, Akbar MA 1993: Effect of urea molasses mineral block supplementation on postpartum ovarian cyclicity in Zebu cows. Animal Reproduction Science 31 61-67.

Haque KS, Akbar MA 1986: Effect of supplementation of Leucaena leucocephala leaf meal to rice straw with poultry excreta or urea on its digestibility in vitro. Bangladesh Veterinary Journal 20 65-71.

Haresign W 1980: Body condition, milk yield and reproduction in cattle. In: Recent Advances in Animal Nutrition, By W Haresign and D Lewis. Butterworth, London, UK, pp. 107-122.

Jackson MG 1977: Rice straw as Livestock feed. Food and Agriculture Organization, World Animal Review 28 38-43.

Jackson MG 1981: Evolving a strategy for Maximum Livestock Production on Minimum Lands. Proceeding of Seminar held in Bangladesh Agricultural University, Mymensingh, February 22-24, Bangladesh.

Joshi DC, Upadhaye RB 1976: Leucaena leucocephala as evergreen protein-rich tree fodder and the possibility of using it in the diet of animals. Indian Journal of Veterinary Science 53 606-612.

Katiyer RC, Ranjhan SK 1969: Yield and chemical composition of Dhaincha (Sesbania aculeata) - its nutritive value for sheep. Indian Journal of Dairy Science 22 33-37.

Khan MAS, Jabber MA, Akber MA, Topps JH 1990: Leucaena leucocephala as an alternative protein supplement to fish meal for lactating cows in Bangladesh. Winter Meeting of British Society of Animal Production, March 18-20, Scarborough, UK.

McNitt JL 1983: Livestock Husbandry Techniques. $1^{\text {st }}$ edn. The English Language Book Society and Granada, London, UK.

Morris RS 1976: Diagnosis of infertility in larger dairy herds. Proceeding \# 28: Refresher Course for Veterinarians, Sydney, Australia.

Neric SP, Aquino DL, Delacruz PC, Ranjhan SK 1984: Effect of urea-molasses-mineral block lick on the growth performances of caracows kept on themeda pasture of central Luzon during the wet season. In: The Use of Nuclear Technique to Improve Domestic Buffalo Production in Asia. International Energy Agency, Vienna, Austria, pp. 127-133.

Patil JS, Deshpande BR 1981: Study of body weight changes during antepartum, parturition and post partum periods in Gir cows with special reference to exhibition of postpartum action. Indian Veterinary Journal 58 376-379.

Peters AR, Riley GM 1982: Milk progesterone profiles and factors affecting postpartum ovarian activity in beef cows. Animal Production 34 145-153.

Preston TR, Willis MB 1970: Intensive Beef Production. Oxford Pergamon Presss, UK.

Rutler LM, Randel RD 1984: Postpartum nutrient intake and body condition: Effect of pituitary function and onset of oestrus in beef cattle. Journal of Animal Science 58 $265-276$. 
Saadullah M, Haque M, Dolberg F 1981: Effectiveness of ammonification through urea is improving the feeding value of rice straw in ruminants. Tropical Animal Production 6 30-36.

Sasser RG, Williams RI, Bull RC, Ruder CA, Falk DG 1988: Postpartum reproductive performance in crude protein restricted beef cows: Return to estrus and conception. Journal of Animal Science 66 3033-3039.

Schiere JB, Nell AJ, Ibrahim MNM 1988: Feeding of urea ammonia treated rice straw. Animal Review 65 31-42.

Steel RGD, Torrie JH 1960: Principles and Procedures of Statistics, Mc-Graw Hill Book Company, Inc. pp. 213-220.

Whishnant CS, Kiser TE, Thompson FN, Hall JB 1985: Effect of nutrition on the LH response to calf removal and GnRH. Theriogenology 24 565-573. 